\title{
The Political Economy of Sustainable Development in Indonesia
}

\author{
Dradjad H. Wibowo ${ }^{1 *}$, Ari Rakatama ${ }^{2}$, Ariyo D.P. Irhamna ${ }^{2}$ \\ ${ }^{1}$ Associate Professor, Perbanas Institute, Jakarta; Chairperson (non-active), the Indonesian \\ Forestry Certification Cooperation (IFCC), Sentul City, Bogor; Indonesia. \\ ${ }^{2}$ Researchers, INDEF (Institute for Development of Economics and Finance), Jakarta, \\ Indonesia. \\ *Corresponding author \\ Email: dhwibowo@ifcc-ksk.org \\ Postal Address: IFCC, Plaza Amsterdam Blok D 56, Sentul City, Bogor, 16810, Indonesia.
}

Received: 22 September 2021 Accepted: 01 November 2021 Published: 27 December 2021

\begin{abstract}
Political economy concerns with how actual policies deviate from economic optimality. This study evaluates Indonesia's progresses toward sustainable development goals (SDGs) from the political economy viewpoint. The authors discuss Indonesia's Voluntary National Reviews (VNRs) and critically analyse its COVID-19 pandemic control policy given the policy's importance to SDG 3 (good health and well-being) and SDG 8 (decent work and economic growth). Indonesia chooses to opt-out strict public health restrictions because of the government's preoccupation with economic growth, the large number of workers relying on daily income and its state of democratic consolidation. This results in Indonesia's failure to control the pandemic and to avert economic recession. Indonesia correctly anticipates global vaccine nationalism and secures adequate vaccine supplies primarily from China. Vaccination becomes Indonesia's key pandemic strategy. This study shows how indispensable partnerships (SDG 17) are for achieving SDGs, presenting the case of the Indonesian Forestry Certification Cooperation's work in forest certification and sustainable forest management.
\end{abstract}

Keywords: political economy, sustainable development goals (SDGs), COVID-19 control policy, sustainable forest management (SFM), IFCC. 


\section{Introduction}

In 2015 all the United Nations (UN) member countries adopted the 2030 Agenda for Sustainable Development which includes a universal call for action to achieve Sustainable Development Goals (SDGs) by 2030. Consisting of 17 goals and 169 targets, SDGs call on countries to join a global partnership to reduce poverty, improve health and education, tackle all forms of inequality, mitigate climate change and undertake other global endeavours to ensure peace and prosperity for all (UNDESA, n.d.). With regard to natural resources, SDGs advance sustainable uses of the world's remaining natural resources amid increased pressures resulting from population and economic growths (ELDInitiative, 2015).

To achieve the goals, countries need to ensure that all three dimensions of sustainable development - economic, social and environmental - are managed in a balanced and integrated manner. Ignoring any one of these dimensions could potentially harm the long-term sustainability of the development process a country is undergoing. As a consequence, many countries, especially in the developing world, find it painstakingly difficult to manage the three dimensions of sustainable development in a balanced and integrated manner. Yet, sustainable development has now been widely recognised as a prerequisite for the long-term health of any country's economic growth (Vinnychuk et al., 2013) and as a non-decreasing element of the intertemporal social welfare (Aidt, 2011).

Recognising the difficulties facing developing countries in taking a sustainable development path, this study aims to provide a critical analysis of SDGs implementation in Indonesia from the political economy viewpoint. As an example of how political economy influences affect SDGs progresses, this study evaluates Indonesia's pandemic control policy in relation to Goals 3 and 8 of the SDGs, termed henceforth SDG 3 and SDG 8, respectively. The first concerns with good health and well-being, while the latter with decent work and economic growth. This evaluation is motivated by the fact that until 2021 the world is still struggling to 
overcome the coronavirus disease of 2019 (COVID-19) pandemic. The pandemic has devastating impacts on the world's economy and people's life, plunging many countries into economic recession and, according to the International Labour Organization (ILO), causing the loss of an equivalent of 400 million full-time jobs in the second quarter of 2020 (ILO, 2020). Given these impacts, a country's capacity to integrate effective pandemic control and economic policies - which are often in contradictory directions - is very crucial for the country's efforts to achieve SDGs 3 and 8.

Because partnerships (SDG 17) play an indispensable role for SDGs, affecting not only processes and outcomes, but more importantly, are very pivotal in determining acceptance by and supports from stakeholders and the wider community, this study also presents SDG 17 implementation as an additional example. This study shows how Indonesian national and local stakeholders work together toward fulfillment of an SDG. The political economy of the development of forest certification by the Indonesian Forestry Certification Cooperation (IFCC) is used as a case study, recognising that sustainable forest management (SFM) contributes to the realisation of several goals, e.g. SDGs 8, 12, 13 and 15 .

The article is organized as follows. The next section presents the methods employed in this study. It is then followed by the results and discussions section outlining (i) a brief review of what political economy and sustainable development mean, (ii) a descriptive discussion on Indonesia's SDGs outcomes based on government reports and claims, (iii) a critical evaluation of Indonesia's pandemic control policy in relation to SDGs 3 and 8, and (iv) an elaborative discussion on the political economy of multi-stakeholder partnerships to achieve SDGs, taking the case of forest certification in Indonesia. The final section concludes the article. 


\section{Methods}

This study employs the mixed-methods research approach that has seen increased uses in economics in the past two decades (Starr, 2014). In this article the authors adopt the definition of mixed-methods research proposed by Johnson et al (2007, p. 123) as follows:

"Mixed methods research is the type of research in which a researcher or team of researchers combines elements of qualitative and quantitative research approaches (e. g., use of qualitative and quantitative viewpoints, data collection, analysis, inference techniques) for the broad purposes of breadth and depth of understanding and corroboration."

Quantitative data and qualitative information are obtained from the Indonesian Voluntary National Review (VNR), official statistics, reports, press releases, news and websites of relevant organizations such the World Health Organization, the Programme for the Endorsement of Forest Certification (PEFC) and IFCC. The authors undertake critical reviews and analyses on those data and information to provide breadth and depth of understanding and corroboration of how political economy influences affect SDGs implementation in Indonesia, as well as to draw up recommendations for policy improvement.

\section{Results and Discussions}

\section{Political economy and sustainable development}

Ancient Greek philosophers and poets had written various political and economic thoughts since the $8^{\text {th }}$ or $7^{\text {th }}$ century BC. The world, however, only knew the term "political economy" from 1615, after French writer Antoine de Montchrétien published his book "Traité de L'œeconomie politique". Political economy as a science was considered born 161 years later with the publication of Adam Smith's "The Wealth of Nations" in 1776. Followed by Thomas Malthus' "An Essay on the Principle of Population" in 1798, the $18^{\text {th }}$ century marked the emergence of political economy as a branch of social science studying the production, 
consumption and distribution of wealth and income in a nation-state, given the nation-state's social, political, legal and government settings.

About a century later, after Alfred Marshall published his seminal book "Principles of Economics" in 1890 the name "political economy" changed into "economics", a short-hand of "economic science". Economics has then been developing into a vast discipline of science, enriched by postulations, axioms, theorems, models and analytical tools adopted from other sciences, most notably mathematics, physics and biology.

Despite having a wide-ranging variety of sub-disciplines, the focus of economics remains on optimal choices for agents working in a setting that meets certain assumptions, such as rational behaviour, perfect competition and efficient market. The assumptions are often so restrictive that they deviate significantly from social, political, legal and government realities. A choice deemed optimal in economics theory could then be a suboptimal one in reality.

With this assumption restrictiveness and its resulting optimality, economics has departed quite afar from its political economy origin. This prompted the emergence of a "new paradigm" called the "new" political economy in the last three or so decades. The new paradigm takes the above-mentioned realities as an integrated setting and internalises market, government and institutional failures back into the theory. The "new" political economy actually brings the “original” political economy back.

Drazen (2000, p. 7) neatly described how political economy responds to deviations from optimality when policy choices are bounded by political or other constraints.

"Political economy thus begins with the observation that the actual policies are often quite different from the optimal policies, the latter defined as subject to technical and informational, but not political constraints. Political constraints refer to the constraints due to conflict of interests and the need to make collective choices in the face of these conflicts. The positive political economy thus asks the question of how political constraints may explain the choice of policies and thus economic outcomes that differ from optimal policies, and the outcomes those policies would imply ..." 
With respect to governments and their policy choices, the following quote from Adam and Dercon (2009, p. 175) shows the realm of political economy.

“... For much of the post-Second World War period ... economics became rooted in what Besley labels a Pigouvian paradigm which stressed the design of optimal policy interventions in the presence of market failure by benevolent social-welfare-maximizing governments ... Notions of government failure or institutional deficiency had no coherent meaning within this paradigm. The 'new' political economy can be seen as a direct response to this limited technocratic characterization of government. It is an attempt to re-focus attention back towards earlier considerations of how politics and the institutional structures emerging from different forms of political competition shape policy choices and ultimately economic outcomes."

In summary, economic optimality is a technocratic and technical conception assuming the absence of market, government and institutional failures. But market is often neither perfectly competitive nor efficient, while governments are not always social-welfaremaximizing. Governments make policy choices amid institutional deficiencies, conflict of interests and other political realities. Political economy studies how actual policy choices and outcomes - not necessarily optimal ones economically - are shaped by all these constraints.

This study adopts the Brundtland report's conception of sustainable development. The report defines sustainable development as "a development that meets the needs of the present without compromising the ability of future generations to meet their own needs" (WCED, 1987). This definition encompasses two dimensions of equity, i.e. intra-generational and intergenerational equities. The first concerns with equity in all facets of life across all segments of the society in the present generation. Social justice forms the foundation of this equity. The latter concerns with equity between present and future generations. This gives rise to the issue of sustainability, ranging from inter-generational allocation of resources and wealth, prevention of future environmental catastrophes to mitigation of climate change.

This definition was then translated into the 2030 Agenda for Sustainable Development containing 17 goals. These goals are: 1) No poverty, 2) Zero hunger, 3) Good health and wellbeing, 4) Quality education, 5) Gender equity, 6) Clean water and sanitation, 7) Affordable and clean energy, 8) Decent work and economic growth, 9) Industry, innovation and infrastructure, 
10) Reduced inequalities, 11) Sustainable cities and communities, 12) Responsible consumption and production, 13) Climate action, 14) Life below water, 15) Life on land, 16) Peace, justice and strong institution, and 17) Partnerships for the goals.

\section{Indonesia's SDGs outcomes}

As reported by the Government of Indonesia (GoI) in the 2017 and 2019 Voluntary National Review (VNR) (GoI, 2019; GoI, 2017), Indonesia has reached many outcomes in achieving sustainable development goals. For SDG 1 (no poverty), the level of poverty in Indonesia declined from $28.32 \%$ in 2006 to $8.80 \%$ in 2015 , measured by Purchasing Power Parity (PPP) of the poverty level of around USD 1.25 per capita/day (WorldBank, 2020). In 2016, 28 million people or $10.86 \%$ of the population lived below the poverty line, decreased from $17.75 \%$ in 2006 . Furthermore, there is a smaller gap between the average expenditure of the poor and the poverty line, indicated by the decline of the Poverty Gap Index (P1) from 3.43 in 2006 to 1.94 in 2016.

For SDG 2 (zero hunger), Indonesia focuses on achieving food security, improving nutrition and promoting sustainable agriculture. The percentage of poor people with a calorie intake of less than $1,400 \mathrm{kcal} / \mathrm{capita} /$ day declined from $41.8 \%$ in 2012 to $32.8 \%$ in 2016 . Although it was still very high, the stunting level was in a downward trend. For children under five years old, the stunting level decreased from $36.6 \%$ in 2002 to $33.6 \%$ in 2016 . Also, for children under two years old, it declined from $36.8 \%$ in 2007 to $26.1 \%$ in 2016.

The Government of Indonesia reported some outcomes for SDG 3 (good health and wellbeing). Ensuring healthy lives and promoting well-being for all ages are among the targets, by reducing maternal and infant mortality, controlling communicable and non-communicable diseases, promoting reproductive health, and improving the National Health Insurance (Jaminan Kesehatan Nasional/JKN) that covers health personnel, medicines and vaccines. Per 
100,000 live births, MMR (Maternal Mortality Rate) dropped from 346 in 2010 to 305 in 2015 (BPS, 2012; BPS, 2016). This means a $2.40 \%$ of Annual Reduction Rate (ARR). The number is not sufficient to achieve the MMR global target (less than 70 per 100,000 live births in 2030) where $9.50 \%$ of the ARR must be achieved. Per 1,000 live births, Infants Mortality Rate (IMR) was stable between 32 and 35 from 2002 to 2012, and Under-five Mortality Rate (U5MR) dropped from 46 in 2002 to 40 in 2012. Moreover, the percentage of completed basic immunisation increased from $41.6 \%$ in 2007 to $59.2 \%$ in 2013 (Kemenkes, 2019) ${ }^{1}$.

Indonesia has achieved near-universal education for SDG 4 (quality education). Between 2015 and 2018, the adjusted net attendance rate at pre-primary education improved from $79.4 \%$ to $83.3 \%$. Also, gross enrolment rate at junior secondary school increased slightly from $91.17 \%$ to $91.52 \%$, at senior secondary school it rose from $78.02 \%$ to $80.68 \%$, and at tertiary level it improved from $25.26 \%$ to $30.19 \%$.

For SDG 5 (gender equity), Indonesia is focusing on gender equality and empower all women and girls. Some important regulations were issued to eliminate women's discrimination such as Law 39/1999 on Human Rights, Law 23/2004 on Elimination of Domestic Violence, Law 12/2006 on Nationality, Law 21/2007 on Eradication of Human Trafficking Crime, Law 2/2008 on Political Party, Law 42/2008 on General Election, and Law 13/2014 as the revision of Law 23/2002 on Child Protection. Government's responsibilities to deliver information, education and services for the reproductive health of adolescences were regulated in Article 136 and 137 of Law 36/2009 on Health. Assurance for women engagement in general elections and requirement of a minimum 30\% of women representation were spelled in Law 8/2012 on General Election. Women and community participation in the planning, implementation and monitoring of village development were regulated in Law 6/2014 on Village.

\footnotetext{
${ }^{1}$ The percentage of children at the age of $12-23$ months having immunization of BCG, measles, and DPT ( 3 doses) and polio.
} 
In targeting SDG 6 (clean water and sanitation), ensuring availability and sustainable management of water and sanitation are the key programs. This was conducted by increasing the number of households with access to safe drinking water and sanitation services. From 2015 to 2018, the proportion of households with access to clean water and sanitation increased from $58.92 \%$ to $61.29 \%$ and from $67.95 \%$ to $74.58 \%$, respectively. Several strategies contributed to this achievement including 1) synergising infrastructure projects such as housing, settlement, clean water and sanitation, 2) improving planning, stakeholders' coordination, and funding, 3) improving roles, capacities, and quality of the local authorities and institutions who manage access to clean water and sanitation; 4) improving community involvement and lifestyle transformation.

For SDG 7 (affordable and clean energy), the government targets electrification ratio, electricity per capita consumption, gas household network (city gas network), renewable energy mix, and primary energy intensity. Energy security is a key to support and to improve the competitiveness of Indonesia's economy. Supply for clean energy and optimisation of gasses and coal usage, as well as minimising import for particular energy resources are some essential steps. Although access to electricity improved, there are still some regions with less than $65 \%$ of the electrification ratio. Despite the government efforts, access to natural gas and electricity for all households remains the main problem in distributing energy services.

Indonesia has achieved some outcomes for SDG 8 (decent work and economic growth) by promoting inclusive and consistent economic growth. Between 2014 and 2018, the GDP developed steadily by $5 \%$ annually, the poverty rate reduced from $10.96 \%$ to $9.66 \%$, and Gini ratio declined from 0.414 to 0.384 . Around 9.38 million new employment opportunities were created, decreasing the unemployment rate from $6.4 \%$ to $5.3 \%$, with the lower female unemployment rate from 2015 to 2018. Furthermore, financial inclusion improved from 36\% 
to $49 \%$, where the financial access for the poorest increased from $22 \%$ to $37 \%$ between 2014 and 2017.

There are some outcomes for SDG 9 (industry, innovation and infrastructure), achieved by building resilient infrastructure, promoting inclusive and sustainable industrialisation and fostering innovation. The first strategy to achieve this goal is by developing qualified, resilient and environment-friendly infrastructures for the public. Secondly, by creating inclusive industrialisation to promote small-scale industries, to increase their access to financial resources, to develop their ability to enter the value chain, and to promote the application of technology and innovation to support sustainable industrialisation. This goal also focuses on ten indicators, including steady road condition, toll road developments, length of the railway, number of airports, number of strategic ports, value-added manufacturing as a proportion of GDP, GDP growth rate of manufacturing industry, government research expenditure as a proportion of GDP, the proportion of population served by mobile broadband, and proportion of mobile phone owners.

For SDG 10 (reduced inequality), from 1999 to 2014 Indonesia's income inequality worsened. The gini ratio rose from 0.31 to 0.41 (Figure 1). Indonesia has improved its income equality slightly during the 2014-2018 period.

Indonesia has achieved some outcomes for SDG 11 (sustainable cities and communities) by creating inclusive, safe, resilient and sustainable cities and settlements. The percentage of low-income group households with access to adequate and affordable housing is the indicator. This goal is achieved by facilitating the provision of adequate and affordable housing, improving housing quality, and financing low-income groups.

To reach some outcomes for SDG 12 (responsible consumption and production), the government works on the implementation of Sustainable Consumption and Production (SCP) patterns in Indonesia. Two indicators were set up to measure the performance. First, "Proper" 
participants achieving at least blue rank. Second, companies applying SNI (Standar Nasional Indonesia) certification of ISO 14001. Also, this goal is achieved by promoting innovative approaches and solutions. This includes policy innovation, stakeholder collaboration, and operational change of practices. Starting from 2019, the government implement green public procurement policy, and educate sustainable lifestyle for communities, develop sharing platform for stakeholder collaboration, and strengthen SCP communication.

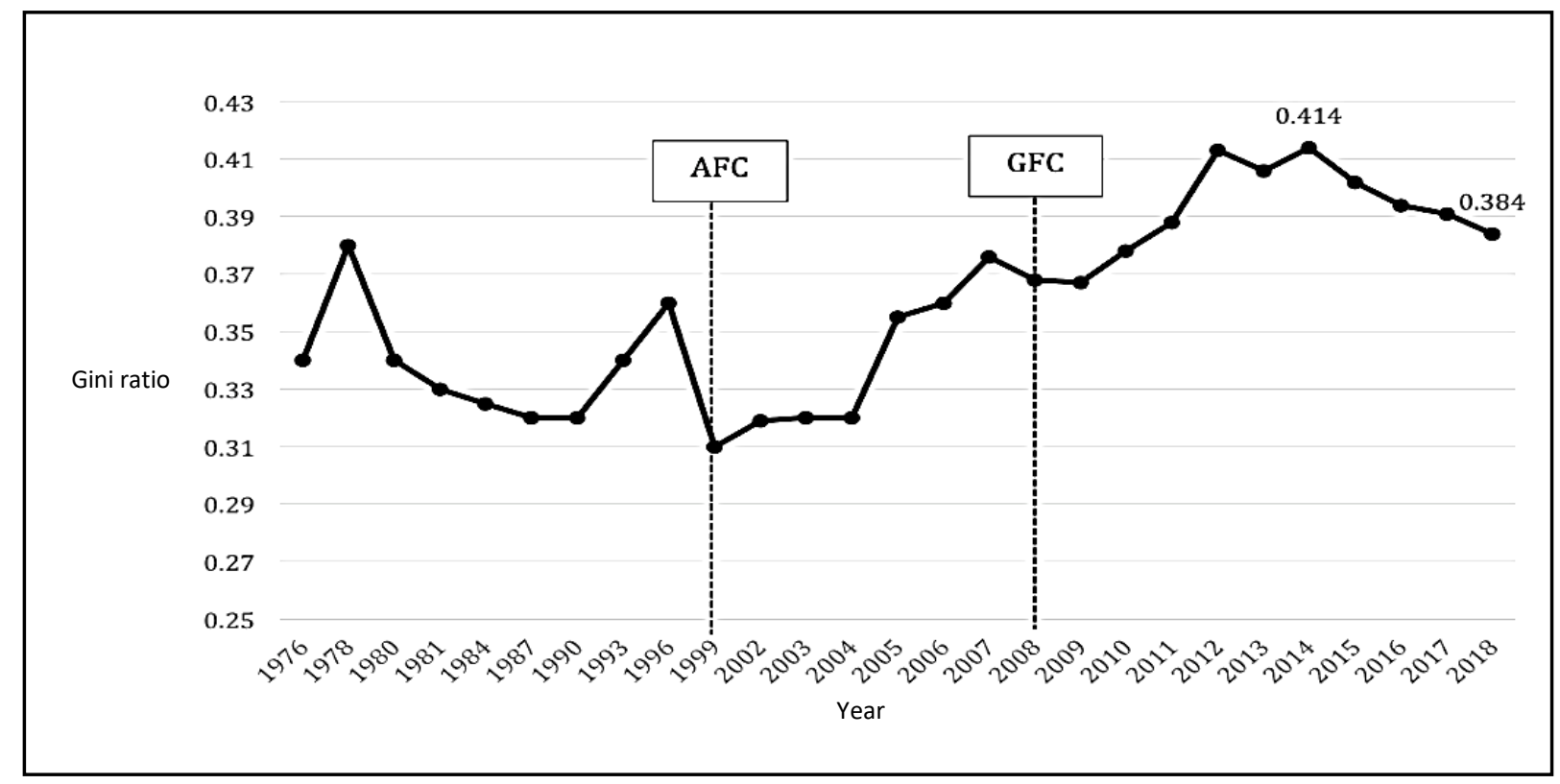

Source: GOI (2019).

Notes: AFC (Asian Financial Crisis), GFC (Global Financial Crisis)

Figure 1. Long Term Inequality Trend (Gini Ratio), 1976-2018

There are several outcomes reported for SDG 13 (climate action) to sustain climate action and manage the disaster. Low Carbon Development becomes a priority of the national development planning agenda. During 2010 - 2017, GHG emission has been decreased by 13 billion ton $\mathrm{CO} 2 \mathrm{e}$ or $22.5 \%$ from the baseline scenario. At the same period, disaster management has been enhanced to reduce the number of deaths and missing persons, decreasing direct economic loss by 7 trillion rupiahs. Furthermore, the Disaster Risk Index has been declined to $23.97 \%$ in 2018. 
For SDG 14 (life below water) Indonesia focuses on conserving and sustainably using the oceans, seas and marine resources. Marine resources and biodiversity in Indonesia play important roles in providing livelihoods for the coastal community and supporting sustainable economic development. Some conservation and sustainable management efforts for marine resources are implemented by conducting spatial planning, implementing Fisheries Management Area (WPP), restricting catch within the biological sustainable level, combating Illegal, Unregulated, Unreported (IUU) Fishing, improving Marine Protected Areas (MPAs), and providing financial access to small-scale fisheries.

Some outcomes for SDG 15 (life on land) has been achieved. Environmental destruction in terrestrial ecosystems was caused by illegal logging, forest and land fires, illegal mining, and non-procedural forest exploitation. The expansion of monoculture plantations is also the driver for the declining wildlife habitat in four major islands (Sumatra, Java, Kalimantan and Sulawesi). Without adequate mitigation efforts, this could reduce forest cover and result in biodiversity loss. The government has implemented some conservation policies by improving forest governance, preserving biodiversity, developing biodiversity economy, and increasing protection on forest ecosystems and genetic resources.

For achieving some outcomes of SDG 16 (peace, justice and strong institution), Indonesia focuses on realizing access to justice and inclusive institutions. From 2016 to 2017, Indonesia's Democracy Index improved from 70.09 to 72.11 . Indonesia has achieved a better AntiCorruption Behaviour Index from 3.59 in 2015 to 3.66 in 2018. At the same period, $\pm 45,000$ legal aid and $\pm 83,000$ non-litigation activities were provided for the poor. Per 2018, birth registration covered $83.55 \%$ of all children in the country ${ }^{2}$.

Outcomes are reported for SDG 17 (partnerships for the goal) by strengthening the means of implementation and revitalizing the global partnership for sustainable development. Two

\footnotetext{
$277.11 \%$ of children in the poorest households, and $71.92 \%$ among under-fives
} 
main points are reported by the government. First, South-South and Triangular Cooperation or SSTC (Kerja Sama Selatan-Selatan dan Triangular/ KSST). Second, the data and statistics to achieve the SDGs.

\section{Evaluating the outcomes: SDGs 3 and 8}

Despite notable progresses in programs such as immunization and provision of safe water and sanitation, the 2017 VNR showed that for a number of basic health indicators, Indonesia was lagging behind the schedule to meet the 2030 SDGs' targets. On maternal mortality ratio (MMR), for example, the 2010 Population Census and the 2015 Intercensal Population Survey reported an MMR of 346 and 305 per 100,000 live births, respectively, representing an annual reduction rate of $2.4 \%$. At this rate of reduction, Indonesia would only be able to reach the 2030 SDGs' MMR target of 70 per 100,000 live birth in 2047.

Clearly, Indonesia needs immense efforts to achieve SDG 3. But amid the global COVID-19 pandemic, nothing is more telling about a country's actions towards SDG 3 than the implementation of effective pandemic control measures. This section reviews Indonesia's preventive responses to control the pandemic, focusing in particular on physical distancing measures and vaccination program.

Since the onset of the pandemic, Indonesia has come under heavy global criticisms for its handling of the pandemic. Global media outlets such as New York Times, BBC, Al Jazeera and Sydney Morning Herald, rating agencies such as Moody's, and non-media sites such as www.carnegieendowment.org and www.aspistrategist.org.au have all been publishing a number of very critical - if not damning - articles about Indonesia's pandemic responses. On February 6, 2020, Indonesia was branded as "a coronavirus time bomb" for not doing enough against the pandemic (Smith, 2020). Allard and Lamb (2020) saw Indonesia's handling of the pandemic as "pure nonsense" with "unscientific approach" resulting in "endless first wave". 
Koetsier (2020) ranked Indonesia at 97 out of 100 COVID-19 safest countries, well below Singapura (4), Vietnam (20), Malaysia (30), Thailand (47), and the Philippines (55). Indonesia's position was even worse than those of Myanmar (83) and Bangladesh (84).

Such heavy criticisms are highly unsurprising given Indonesia's initially abysmal handling of the pandemic. Throughout February 2020, the minister of health and other senior government officials boasted a claim that Indonesia remained free of COVID-19, even though the neighboring Singapore, Malaysia and Australia had all reported positive cases. These officials advanced scientifically unfounded reasoning, including among others, tropical climate, consumption of jати (traditional herbal medicines) and Indonesians having some kinds of race-related immunity. Case detection failure due to inadequate testing was never mentioned. The government went even further by announcing travel discounts for foreign tourists, in contrast to border closing that neighbouring countries began to install.

Sciences and international best practices show that to control a pandemic, in addition to adequate testing and tracing program, community-wide physical (social) distancing measures need to be applied in a rigorous and disciplined manner. These measures, termed "large-scale public health restrictions" by the World Health Organization (WHO, 2020), usually include border closing, movement restriction, school, workplace, and public-place closures, prohibition of gatherings, isolation and or quarantine.

Indonesia did not apply these measures swiftly after confirmation of the first COVID-19 case on March 2, 2020. For over a month, no meaningful public health restrictions were put in place. The government also wrote quarantine off because it could not afford providing basic foods and necessities to the affected population, as provisioned by the Health Quarantine Bill (Law No. 6/2018). Instead, on March 31, 2020, the government issued Government Regulation No. 21/2020 on "Large Scale Social Restriction" known nationally as the PSBB, and delegated the PSBB responsibility to provincial and city/district governments. Thirty-nine days after the 
first case was officially acknowledged, on April 10, 2020, the Capital Province of Jakarta applied the PSBB, followed by some cities and districts in the island of Java.

In June 2020, a number of Indonesia cities began to ease the PSBB and replaced it with more relaxed measures called transitional PSBB and "people's activities limitation". This relaxation was taken despite the fact that Indonesia's daily cases were still on the rise and the country's COVID-19 transmission was still on an upward state as shown by its health production function. Throughout June 2020 Indonesia's COVID-19 production elasticity was shown to vary between 2.12 and 3.07 with a rising marginal product, meaning that the country was still in the red transmission zone (Wibowo, 2021). In this zone, physical distancing measures shall not be eased.

From June 2020 to January 2021 period, no meaningful public health restrictions were applied. Government offices, shopping malls, eating places, and other public places remained open albeit with reduced activities. Buses and other city transportation vehicles stayed operational, with virtually no enforcement of distancing inside the vehicles. Airlines, railways, buses, ferries and ships were still allowed to operate, with a cap on the number of passengers per vehicle. Inter-city train passengers were required to show a non-reactive rapid antibody test result, which from December 22, 2020 was replaced by a negative rapid antigen result. Airline passengers had to show a negative Polymerase Chain Reaction (PCR) test result. Travels by government officials were encouraged. Economic ministers even held cabinet coordination meetings in the tourist destination islands of Bali and Bintan. The aim was to boost government spending and economic growth.

Preventive measures such as mask wearing, distancing, hand washing and temperature checking were applied relatively strictly in formal public places such as banks, office buildings, airports and other formal places. But in places such as hawker centres, traditional markets and kampungs (lower class urban neighbourhoods), most people visibly ignored these measures. 
On January 13, 2021, Indonesia began its mass COVID-19 vaccination using CoronaVac, a vaccine developed by Chinese biopharmaceutical company Sinovac Biotech Ltd. Two days earlier on January 11, 2021, Indonesia's Drug and Food Supervision Agency (BPOM) had issued an Emergency Use Authorization (EUA) for CoronaVac after announcing the vaccine's efficacy of $65,3 \%$. This issuance made Indonesia the first country in the world that officially approved the use of CoronaVac.

Sinovac works with the 130-year-old state-owned company PT Bio Farma (Persero) in producing the vaccine for Indonesia. In this collaboration, Bio Farma purchases 3 million doses of readily-used CoronaVac and 140 million doses of bulk vaccine raw material. Bio Farma will carry out the fill finish process for the bulk raw material to produce 122.5 million doses of vaccine. Bio Farma also helps Sinovac conducting the vaccine's Phase 3 trial, together with Padjadjaran University's Faculty of Medicine.

The trial began on August 11, 2020 in the city of Bandung, involving 1620 volunteers from the 18-59 age cohort, with an interim report expected to be completed by the end of January 2021. It is worth noting that on July 21, 2020, President Joko Widodo asked the Padjadjaran University's research team to ensure vaccine availability within three months, which the team correctly explained that it is scientifically not possible.

Concerns over lack of transparency, however, clouded the trial and the subsequent issuance of the EUA. The interim report was submitted to the BPOM on January 7, 2020, but the BPOM did not release details of the report. The BPOM announced the efficacy figure, but not the number of volunteers receiving treatment and placebo, nor the number of those who got infected in each group. Consequently, the attack rate in each group was not known publicly. The fact that Brazil and Turkey announced a CoronaVac's efficacy of $78 \%$ (revised later to $50.4 \%$ ) and $91.25 \%$, respectively, raised further questions about the efficacy. 
A few hours after the BPOM announcement, quoting unnamed official Widianto (2020) reported that the efficacy figure comes from 25 infections during the trial. Based on this report, Wibowo (2020) calculated 6 and 19 infections within assuming that the volunteers were split evenly between the groups. When contacted by a Tempo journalist on January 14, 2021, Head of the Phase 3 trial team confirmed that among 1603 volunteers there were 7 and 18 infections in the vaccinated and the placebo groups, respectively (Rusmil, 2020). Assuming an even distribution of the volunteers, the authors estimated an attack rate of $0.87 \%$ among the vaccinated and 2.25\% among the placebos. Rusmil (2020) also reported immunogenicity of $99 \%$. It is obviously very concerning to experience that all these key data had to come from an unnamed official, an outsider's calculation and a journalist's questions.

Indonesia had already received 1.2 million doses of readily-used CoronaVac on December 6, 2020 and a further 1.8 million doses on December 31, 2020. In a cabinet meeting on January 6, 2021, President Joko Widodo announced that mass vaccination would begin in the following week and the government had started vaccine distribution on January 3, 2021. All these events took place before BPOM received the Phase 3 trial's interim report. A day after the BPOM issued the EUA, a delivery of 15 million units of bulk raw material equaling to 12 million doses of vaccine arrived.

Indonesia's vaccination drive is targeting 181.5 people in two phases. The first phase runs from January to April 2021 targeting 1.3 millions of health care professionals and 17.4 millions of public service officials. The second phase starts from April 2021 to March 2022 targeting the rest of the population including 21.5 million elderly ( $\geq 60$ yo). The CoronaVac, however, will only be given to individuals in the 18-59 cohort in accordance with the Phase 3 trial's cohort. To quell public scepticism, on January 13, 2021, President Joko Widodo became the first person receiving CoronaVac. A number of ministers and public figures, including popular actors and social media influencers, also received the vaccine on the same day. 
In addition to Sinovac, as of January 2021, Indonesia either has secured a contract or is in the process of negotiating one with other vaccine manufacturers such as Novavax, AstraZeneca/Oxford and Pfizer/BioNTech. Indonesia also applies for COVAC facility co-led by GAVI, the Coalition for Epidemic Preparedness Innovations (CEPI) and WHO. An effort to develop a national vaccine called the Red and White vaccine is also underway.

Given its relaxed public health restrictions, it comes as no surprise that Indonesia showed worse prevalence and mortality rate than countries regarded as among the world's best in pandemic control. This study uses Vietnam and Taiwan as examples of these countries.

Table 1 shows that as of December 31, 2020, Indonesia's COVID-19 prevalence was 80 to 180 times higher than those of Vietnam and Taiwan. Indonesia's mortality rate came even worse, around 202 to 270 times of Vietnam's and Taiwan's. With the number of COVID-19 deaths in Indonesia rises, while that in Vietnam and Taiwan relatively unchanged, Indonesian mortality rate looks set to worsen further in early 2021.

Table 1. COVID-19 prevalence and mortality rate and GDP Growth in Indonesia, Vietnam and Taiwan as of December 31, 2020

\begin{tabular}{lrrr}
\multicolumn{1}{c}{ Countries } & \multicolumn{1}{c}{ Indonesia } & \multicolumn{1}{c}{ Vietnam } & \multicolumn{1}{c}{ Taiwan } \\
\hline Population 2020 & $273,523,621 \mathrm{a})$ & $97,338,583 \mathrm{~b})$ & $23,561,236 \mathrm{c})$ \\
COVID-19 & & & \\
Cases & $743,198 \mathrm{~d})$ & $1,456 \mathrm{~d})$ & $799 \mathrm{e})$ \\
Death & $22,138 \mathrm{~d})$ & $35 \mathrm{~d})$ & $7 \mathrm{e})$ \\
& & & \\
COVID-19 / 100,000 people & & & 3.39 \\
Prevalence & 271.71 & 0.04 & 0.03 \\
Mortality rate & 8.09 & & \\
& & & \\
GDP growth $(\boldsymbol{\%}, \mathbf{y - 0 - y )})$ & 2.97 & 3.82 & 2.51 \\
Q1/2020 & -5.32 & 0.39 & -0.58 \\
Q2/2020 & -3.49 & 2.62 & 1.59 \\
Q3/2020 & -2.19 & 4.48 & 4.94 \\
Q4/2020 & & & \\
\hline
\end{tabular}

Sources:

a) https://data.worldbank.org/indicator/SP.POP.TOTL?locations=ID

b) https://data.worldbank.org/indicator/SP.POP.TOTL?locations=VN

c) https://www.ris.gov.tw/app/en/3912

d) WHO Coronavirus (COVID-19) Dashboard, https://covid19. who.int

e) https://ourworldindata.org/coronavirus/country/taiwan

f) Each country's national statistical office. GDP = gross domestic product. 
The risk of sharp economic downturns is often cited as an argument against strict public health restrictions to control a pandemic. However, Table 1 gives initial evidence that countries which successfully suppress transmission of COVID-19 perform better economically than those who do not. Vietnam maintained a positive economic growth from Q1/2020 to Q3/2020, which even accelerated into $4.48 \%$ in Q4/2020. This is an exceptional accomplishment in the pandemic-subdued global economy. Taiwan's economy rebounded quickly in Q3/2020 and accelerated sharply by $4.94 \%$ in Q4/2020 after recording a negative growth in Q2/2020. Indonesia on the contrary entered a recession from Q2/2020 to Q4/2020.

A number of reasons explain Indonesia's inadequate public health responses to the pandemic. The authors will outline three reasons considered the most crucial ones. Firstly, overly preoccupied with preserving economic growth, the Indonesian government mistakenly viewed large-scale public health restrictions as a detriment to this goal. President Joko Widodo famously stated on July 15, 2020, that had Indonesian applied a strict lockdown, economic growth could fall sharply to minus $17 \%$.

Such a fear might be justified for a short-term period. Lockdown and other strictest forms of public health restrictions do have very high short-term economic costs. The Organisation for Economic Co-operation and Development (OECD), for example, projected that in a single-hit pandemic scenario the world's economy would contract by $6 \%(\mathrm{OECD}, 2020)$. But Correia et al (2020) showed that during the 1918 flu pandemic the US cities that applied nonpharmaceutical interventions such as social distancing aggressively earlier had their economies recovering quickly after the pandemic. The case of Vietnam and Taiwan gives another evidence that successful pandemic control can lead to a better economic performance.

Secondly, Indonesia has a large number of labourers and informal workers relying on daily income. According to the Indonesian Central Statistics Agency (BPS), the number of 
employments in Indonesia in August 2020 was 128.45 million of 138.22 million workforces. The majority of those with a job, around 77.67 million people or $60.47 \%$ of the employed, were informal workers earning non-regular income from either agricultural or non-agricultural jobs. Of those employed formally, around 17.48 million worked in the manufacturing industry, a large portion of them earning a daily wage. For these workers, being confined at home means a loss of daily income, and with the government fiscally unable to compensate for their loss of income, it consequently means being unable to provide for their family. An assertion like "Dying of COVID-19 or starvation? I would rather take my chance with the disease as long as I can feed my family" became a widely-shared expression. Thus, working from home has never been an option for these millions of workers, making it virtually impossible to apply the strictest forms of public health restrictions.

Thirdly, following the 1998 reformation Indonesia has undergone a transformation from authoritarianism towards democracy, and is currently in the process of democratic consolidation. Fair elections, rule of law, civil society, independent judiciary and freedom of the press are being developed and consolidated despite obstacles such as steep education and income disparities among various elements of the society. Given this democratic consolidation, imposing a strict public health restriction, quarantine for example, might be misconstrued as a return to authoritarianism. In 2020 Indonesia also needed to hold governortarial and mayoral elections or the Pemilihan Kepala Daerah (Pilkada) in 9 provinces, 224 districts and 37 cities. To postpone the Pilkada until after the pandemic was constitutionally contentious, leading to grave legitimacy doubts over a half of the number of governments across the nation.

Given the above obstacles to apply strict public health restrictions, Indonesia relies heavily on mass vaccination to reach herd immunity. This has now become the country's main strategy to control the pandemics and to revive its economy. The Indonesian government correctly anticipated a global realpolitik scenario where developing countries are unable to 
secure adequate supplies of COVID-19 vaccines, especially the ones developed by advanced countries. This relates to a phenomenon called vaccine nationalism, where the wealthiest nations prioritise supplies for their own populations. Because Indonesia has been developing a significantly much closer relationship with China in the past few years, the government decided to secure the majority of its vaccine needs from Sinovac, and tasked Bio Farma to carry out the vaccine's fill finish process. Indonesia via Bio Farma is at present the largest buyer of Sinovac's CoronaVac with the possibility of Bio Farma becoming the fill finish manufacturer for the ASEAN market.

Because COVID-19 vaccines give only a short-lived immunity, hence the need of continuous revaccination, to secure supplies for future needs Indonesia develops its own Red White (RW) vaccine (vaksin Merah Putih), taking the name from the Indonesian national flag. The government brings in six leading institutions and universities, i.e. the Eijkman Institute for Molecular Biology, the Indonesian Institute of Sciences (LIPI), the University of Indonesia (UI), the Airlangga University (UNAIR), the Gadjah Mada University (UGM) and the Bandung Institute of Technology (ITB). Each institution or university employs a different vaccine platform technology, with the Eijkman Institute, UI and UNAIR expected to progress to Phase 1 trial in April/May 2021.

\section{SDG 17 (partnerships for the goals): The case of SFM and forest certification}

Shortened into partnerships for the goals, SDG 17 officially reads "strengthen the means of implementation and revitalize the global partnership for sustainable development". SDG 17 has 19 targets, of which Target 17.16 states "Enhance the global partnership for sustainable development, complemented by multi-stakeholder partnerships that mobilize and share knowledge, expertise, technology and financial resources, to support the achievement of the sustainable development goals in all countries, in particular developing countries." 
The keyword for SDG 17 is partnership. It calls for a global partnership for sustainable development, complemented by multi-stakeholder partnerships. The United Nations defines partnership as "voluntary and collaborative relationships between various parties, both public and non-public, in which all participants agree to work together to achieve a common purpose or undertake a specific task and, as mutually agreed, to share risks and responsibilities, resources and benefits." (UNDESA, 2015).

Forest certification provides an excellent example of how inevitable partnerships are for the fulfillment of SDGs. Forest certification is a market-based instrument involving two processes: SFM certification and chain of custody $(\mathrm{CoC})$ certification. It conveys a product messaging to the marketplace that the certified products, throughout all stages of their supply chains, come from sustainably managed forests. It helps producers, consumers and all concerned stakeholders to join forces to ensure implementation of SFM in the production, distribution and consumption of forest-based products.

In developing their standards, forest certification schemes around the world usually take an SFM definition given by an official multilateral forum. They then develop their standards accordingly, which include criteria, indicators, procedures and guidance. Criteria refer to the "essential components" of SFM; indicators specify ways to assess and audit each SFM component; procedures govern the functioning of a scheme including, among others, trademark procedures; and guidance provide additional directions and advices on certain criteria, indicators or procedures.

The Geneva-based Programme for the Endorsement of Forest Certification (PEFC), for example, uses the Ministerial Conference on the Protection of Forests in Europe or Forest Europe's definition of SFM adopted by FAO. It defines SFM as "The stewardship and use of forests and forest lands in a way, and at a rate, that maintains their biodiversity, productivity, regeneration capacity, vitality and their potential to fulfil, now and in the future, relevant 
ecological, economic and social functions, at local, national, and global levels, and that does not cause damage to other ecosystems" (PEFC, n.d.). This definition becomes the basis for the development of PEFC's benchmark standards and guides, and national schemes need to meet these benchmarks to get PEFC endorsement. PEFC is the largest forest certification scheme in the world, with over 320 million hectares of forest holding its SFM certificate and over 20,000 companies from 70 countries holding its CoC certificate.

Another global scheme, the Bonn-based Forest Stewardship Council (FSC), gives no official definition of SFM but its website states that "FSC forest management certification confirms that the forest is being managed in a way that preserves biological diversity and benefits the lives of local people and workers while ensuring it sustains economic viability" (FSC, n.d.).

For tropical forests, the International Tropical Timber Organization (ITTO) defines SFM as "the process of managing forest to achieve one or more clearly specified objectives of management with regard to the production of a continuous flow of desired forest products and services without undue reduction of its inherent values and future productivity and without undue undesirable effects on the physical and social environment" (ITTO, n.d.). Since the early 1990s, ITTO has been leading the development of criteria and indicators (C\&I) for sustainable tropical forest management. In 2016 ITTO released a revised version of ITTO C\&I, consisting of 7 criteria and 58 indicators (ITTO, 2016). ITTO C\&I have since the 1990s become key references for many tropical timber countries in developing their SFM policies.

With those definitions, plus the C\&I that elaborate them, SFM serves several SDGs. SFM directly serve SDG 15 because the goal's statement includes the phrase "sustainably managed forests". Realisation of SFM by a forest operation, as validated by a globally recognised SFM certificate, means that in the operation's area a large number of SDG 15's targets have been met, from ending deforestation and restoring degraded forest to financing SFM. SDG 8 is also 
served because SFM facilitates a more sustainable economic growth, creates employment, protects labour rights and promotes safe working environments. Furthermore, because SFM ensures adoption of sustainable production and consumption practices, as well as represents an urgent action to combat climate change, SFM also serves SDGs 12 and 13, respectively.

Forest certification schemes provide instruments to assess if SFM is achieved. This assessment uses the criteria, indicators and procedures that a scheme employs. But in order for forest certification to work, multi-stakeholder partnerships at the global, national and local levels are a must. All stages in the establishment of a forest certification scheme, from standard development to global market acceptance, cannot be carried out without a multi-stakeholder partnership. Otherwise, a stakeholder may reject an element of the scheme, and as a result the scheme may not be able to gain market credibility and acceptance. From the forest operation side, a forest operation needs such a multi-stakeholder partnership to undertake the necessary cultural and operational transformations to meet SFM C\&I. Without these transformations, SFM cannot be realized, and consequently, there are no certifiable forest operations.

The case of the Indonesian Forestry Certification Cooperation (IFCC) illustrates how indispensable a multi-stakeholder partnership is for forest certification, SFM and SDGs. IFCC was established on September 9, 2011 by a number of non-governmental organizations (NGOs) and private businesses. The geo-political economy situation at the time saw a number of multinational corporations boycotted Indonesian pulp and paper products amid pressures from global NGOs such as Greenpeace. The NGOs claimed that the products come from unsustainable plantation forests. Mindful of this geopolitical economy setting, IFCC aims to promote SFM in Indonesia by the implementation of a PEFC-endorsed certification scheme. IFCC became PEFC's national governing body (NGB) for Indonesia on November 16, 2012. IFCC founders incorporated the word "cooperation" in the organisation's name to highlight that partnership is the spirit of the organisation. This spirit translates into IFCC's 
consultation-and-consensus based decision-making. The highest level decision-making body within IFCC is the Members General Meeting. As of 2020 IFCC has 53 members, grouped into the civil society caucus (32 members) and the business caucus (21 members).

IFCC's SFM certification scheme is developed by a Standardising Committee involving representatives from eight groups of stakeholders: a) business and industry, b) women, youth, and children, c) forest owners/managers, d) indigenous communities, e) government authorities, f) NGOs, g) scientific and technological community, and h) workers and trade union. The first SC was formed in 2013, comprising of 42 members.

On October 1, 2014, PEFC endorsed IFCC's SFM scheme. The first PEFC certificates for Indonesian forest operations were issued in 2015. By 2018, virtually all Indonesian plantation forests established before PEFC's cut-off date of December 31, 2010 had been certified. This amounted to around 4 million hectares of forests, none of them is natural, nor old growth nor HCV (high conservation value) forests. After almost 2.4 million hectares of forests were certified in 2016, Indonesian pulp and paper export which had continued to decline since 2010 recorded an increase of around 20\% (US\$ 1 billion) in 2017.

The rest of Indonesian plantation forests, around 900 thousand hectares, are not eligible for IFCC/PEFC certification because they were converted from primary forests after 31 December 2010. IFCC postponed its SFM certification program for community forests, scheduled to commence in 2020 , because of the pandemic.

In addition to the SFM certificate, a total of 38 Indonesian companies received PEFC's CoC certificate as of 2020 . They include popular copy paper and paper tissue brands, and some household names in the online shopping, airline and publishing industries. An expansion to other paper-using industries and the fashion industry is expected in the years ahead.

Without global and multi-stakeholder partnerships, those progresses were likely beyond IFCC's reach. It can be explained as follows. Firstly, past experience shows that national 
schemes need time- and resources-consuming efforts to gain a global market acceptance. Such was experienced by national schemes developed in the 1990s and early 2000s such as Indonesia's LEI, Malaysia's MTCC, Brazil's Cerflor and North America's SFI and ATFS. By joining a global partnership of national schemes, for example, under a global umbrella organization like PEFC, a global market acceptance can be secured. Without this acceptance, a forest certification scheme will cease to exist or become irrelevant. Secondly, IFCC follows PEFC's standards and guides. These standards and guides are products of a global partnership involving PEFC members and stakeholders. They require employment of multi-stakeholder partnerships for national standard development, reflected in membership of the standardising committee. Thirdly, certification audits also need a multi-stakeholder partnership. Before issuing an SFM certificate, a certification body must release its audit report summary for public consultation involving stakeholders where inputs and objections can be raised and resolved. Fourthly, IFCC's SFM certification scheme demands forest operations to institute a functioning partnership with stakeholders such as local and or indigenous communities. This partnership shall include economic benefit sharing. All these show that partnerships are inevitable for forest certification and in turn for the fulfilment of SFM and SDGs.

\section{Conclusion}

With regard to SDGs 3 and 8, this study highlights lessons learned from the failure of the Indonesian government in anticipating COVID-19 outbreak at the early stages of the pandemic. Avoiding scientifically recommended measures such as strict restriction on people's mobility and border closing led to the unsuccessful story of Indonesia in preventing the pandemic. Although opting out from such measures aimed to maintain economic growth, it has instead brought the country's economy into the opposite direction. While countries implementing strict public health restrictions since the very beginning of the pandemic, such as Taiwan and 
Vietnam, were achieving economic recovery, Indonesia was still struggling with its economic recession.

Recently, the Indonesian government move forward to another strategy by focussing on the national vaccination program to achieve herd immunity as soon as possible. It is conducted by securing adequate vaccine supplies, producing in-country vaccines, and developing a national vaccine. This strategy is logical considering that more than half of the Indonesian workforces are working informally and heavily depending on daily income, making restriction on people's mobility extremely difficult. Moreover, as a democratic country upholding freedom of speech, public health restrictions could be seen as an authoritarian policy by the government, which could lead to people resistance.

Regarding SDG 17, this study shows how crucial multistakeholder partnership is in achieving SFM and forest certification, as well as to reach an optimality among economic benefits, social justice, and environmental protection. Ensuring sustainable forest management by implementing globally recognized, trusted, and reliable schemes of forest certification could address several SDGs such as SDG 8 (decent work and economic growth), SDG 12 (responsible consumption and production), SDG 13 (climate action), and SDG 15 (life on land).

This study recommends that the Indonesian government should move forward with the implementation of national vaccination agenda. Improving the capacity of bureaucracy and avoiding political interference are crucial in combating the COVID-19 pandemic and recovering economic growth. The government should also enhance global partnership such as with the European Union on forestry as well as improve domestic public awareness on sustainability issues and programs to achieve sustainable development goals.

This study is concerned only with the political economy of SDGs 3, 8, and 17 in Indonesia. Similar studies on other SDGs in Indonesia and other countries would give a more 
complete picture of the political economy of SDGs and are therefore strongly recommended by the authors.

\section{Acknowledgement}

We thank the Indonesian Forestry Certification Cooperation (IFCC) for sponsoring this study.

\section{References}

Adam C and Dercon S. (2009), The political economy of development: an assessment. Oxford Review of Economic Policy 25: 173-189.

Aidt TS (2011), Corruption and sustainable development. International handbook on the economics of corruption 2: 3-51.

Allard T and Lamb K (2020), Endless first wave: how Indonesia failed to control coronavirus. Available at: https://www.reuters.com/article/us-health-coronavirusindonesia-insight-idUSKCN25G02J. [accessed 4 February 2021].

Besley T (2007), The new political economy. The Economic Journal 117: F570-F587.

BPS (2012), Penduduk Indonesia Hasil SP2010. Jakarta: Badan Pusat Statistik.

BPS (2016), Profil Penduduk Indonesia Hasil SUPAS. Jakarta: Badan Pusat Statistik.

Correia S, Luck S, Verner E. (2020), Pandemics depress the economy, public health interventions do not: evidence from the 1918 Flu. Published online March 30, 2020. Available at: http://dx.doi.org/10.2139/ssrn.3561560 [accessed 6 June 2020].

Drazen A (2000), Political economy in macro economics, Princeton, New Jersey: Princeton University Press.

ELDInitiative (2015), The Value of land: prosperous lands and positive rewards through sustainable land management.

FSC (n.d.), Forest management certification. Available at: https://fsc.org/en/forestmanagement-certification [accessed 4 February 2021]. 
GoI (2017), Voluntary National Review (VNR) 2017: “Eradicating Poverty and Promoting Prosperity in A Changing World". Jakarta.

GoI (2019), Voluntary National Review (VNR) 2019: "Empowering People and Ensuring Inclusiveness and Equality". Jakarta.

ILO (2020), As jobs crisis deepens, ILO warns of uncertainty and incomplete labour market recovery. Available at: https://www.ilo.org/global/about-the-

ilo/newsroom/news/WCMS_749398/lang--en/index.htm [accessed 4 February 2021].

ITTO (n.d.), Sustainable forest management. Available at:

https://www.itto.int/sustainable_forest_management/ [accessed 4 February 2021].

ITTO (2016), ITTO releases new edition of $C \& I$. Available at:

https://www.itto.int/news_releases/id=4873 [accessed 4 February 2021].

JHU-CSSE (2020), COVID-19 Data Repository. In: (CSSE) JHU-CfSSaE (ed).

Johnson RB, Onwuegbuzie AJ, and Turner LA (2007), Toward a definition of mixedmethods research. Journal of Mixed Methods Research. DOI:

https://doi.org/10.1177/1558689806298224 [accessed 19 September 2021].

Kemenkes (2019), Hasil Utama Riskesdas 2018. Jakarta: Kementerian Kesehatan RI.

Koetsier J (2020), The 100 safest countries in the world for COVID-19. Available at:

https://www.forbes.com/sites/johnkoetsier/2020/06/05/the-100-safest-countries-inthe-world-for-covid-19/?sh=36867ece68c5. [accessed 4 February 2021].

North DC (1990), Institutions, institutional change and economic performance, New York:

Cambridge University Press.

OECD (2020), OECD economic outlook, June 2020: the world economy on a tightrope.

OECD, Paris, June 2020. Available at: http://www.oecd.org/economic-outlook/june2020/ [accessed 12 June 2020].

PEFC (n.d.), Discover PEFC. Available at: https://pefc.org/discover-pefc. [accessed 4 February 2021].

Rusmil K (2020) in Siswadi A and Wuragil Z (2020), 25 Relawan uji vaksin Sinovac di Bandung positif COVID-19. Tempo, Januari $17^{\text {th }}, 2021,19.15 \mathrm{pm}$. Available at https://tekno.tempo.co/amp/1424134/25-relawan-uji-vaksin-sinovac-di-bandungpositif-covid-19 [accessed 4 February 2021]. 
Smith T (2020), Australia's biggest neighbour may be a coronavirus time bomb: World's peak health body worried Indonesia isn't doing enough to guard against disease. Available at: https://www.dailymail.co.uk/news/article-7971933/Worlds-peak-healthbody-worried-Indonesia-isnt-doing-guard-against-disease.html. [accessed 4 February 2021].

Starr MA (2014), Qualitative and mixed-methods research in economics: Surprising growth, promising future. Journal of Economic Surveys 28(2): 238-264. DOI: https://doi.org/10.1111/joes.12004 [accessed 19 September 2021].

UNDESA (2015), Partnerships for sustainable development goals: A legacy review towards realizing the 2030 Agenda. Available at: https://sustainabledevelopment.un.org/sdinaction/publication/partnerships-a-legacyreview [accessed 4 February 2021].

UNDESA (n.d.), Sustainable development: the 17 goals. Available at: https://sdgs.un.org/goals. [accessed 4 February 2021].

Vinnychuk O, Grygorkiv V and Makhanets L (2013), Research of economic growth in the context of sustainable development: neural network approach. Business Systems \& Economics 3: 153-166.

World Bank (2020), Poverty \& equity brief: Indonesia. Available at: https://databank.worldbank.org/data/download/poverty/33EF03BB-9722-4AE2ABC7-AA2972D68AFE/Global_POVEQ_IDN.pdf. [accessed 4 February 2021].

WCED (1987), Our common future, Oxford: The World Commission on Environment and Development, Oxford University Press.

WHO (2020), Strengthening and adjusting public health measures throughout the COVID-19 transition phases. Policy considerations for the WHO European Region. WHO Regional Office for Europe, Copenhagen. Available at: https://www.euro.who.int/en/health-topics/health-emergencies/coronavirus-covid19/technical-guidance/2020/strengthening-and-adjusting-public-health-measuresthroughout-the-covid-19-transition-phases.-policy-considerations-for-the-whoeuropean-region,-24-april-2020 [accessed 7 June 2020].

Wibowo DH (2021), When can physical distancing be relaxed? A health production 
function approach for COVID-19 control policy. BMC Public Health 21 (1037). DOI:

https://doi.org/10.1186/s12889-021-11088-x [accessed 14 June 2021].

Widianto S (2020), Indonesia approves China's Sinovac vaccine as infections surge. Reuters, January $11^{\text {th }}, 2021,04.05$ pm. Available at: https://www.reuters.com/article/us-healthcoronavirus-indonesia/indonesia-approves-chinas-sinovac-vaccine-as-infectionssurge-idUSKBN29G0RP [accessed 4 February 2021].

Sustainability Science and Resources (SSR) is jointly published by the Indonesian Forestry Certification Cooperation (IFCC), in collaboration with Millennium Resource Alternatives (MRA) LLC and Sustainable Development Indonesia (SDI). All articles are published in full open access, freely and permanently available online without registration restrictions or subscription charges, immediately upon publication. Authors are the copyright holders of articles published in SSR, but by publishing in this journal they have agreed to grant the right to use, reproduce and or disseminate their articles to any third party. All articles published in SSR are licensed under the terms of the Creative Commons Attribution 4.0 International License. 